Original

\title{
Skin Lesions Observed During Shearing in 338 Alpacas (Vicugna Pacos) in South Australia
}

\author{
南オーストラリアでの 338 頭のアルパカ（Vicugna Pacos）における \\ 剪毛時での皮膚病変の観察
}

\author{
Thomas W. Westermann*, Peter B. Hill, Mandi N. Carr \\ School of Animal and Veterinary Sciences, The University of Adelaide
}

Received October 16, 2015 and accepted January 7, 2016

\begin{abstract}
Objective: To identify the prevalence of skin lesions in a population of alpacas in South Australia, and to determine their distribution on the skin surface. Methods: A survey was conducted by professional alpaca shearers over a 16 day period during spring 2013 in three different geographical regions within South Australia. Skin lesions were observed and recorded using a Skin scoring chart, allowing for 11 different lesion types and 15 body areas. Results: Data were available from 338 alpacas, of which $60.4 \pm 5.2 \%$ had one or more skin lesion. The most commonly observed lesions were scale and lichenification, crust, alopecia and erythema, each observed over 300 times. The most commonly affected areas were the fore and hind legs, axillae and hind feet. There was a significant association between lesion types and their anatomical location (Chi square test, $\mathrm{p}<0.0001)$. Conclusion: This survey of a subpopulation of South Australian alpacas has identified skin lesions in approximately $60 \%$ of subjects. Based on their location, the majority of lesions observed would not greatly influence the value of the fleece.

Key words: alpaca, camelid, skin, dermatology, lesion

要 約：目的：南オーストラリアでのアルパカ群の皮膚病の有病率の決定，およびそれらの皮膚表 面の状態を確認するため。方法：南オーストラリアでの異なった 3 地域において, 2013 年春期の 16 日間にわたり，アルパカを専門的に剪毛する職人の貢献による。皮膚病変は，11の異なった皮 膚症状および体表を 15 個所に分けたボディスコア表に従って記録した。結果：338頭のアルパカ からデータが得られ，それらのうち $60.4 \pm 5.2 \%$ ぞまたは二か所の皮膚病変を保持していた。最 も多く認めた皮膚症状として, 鱗屑および苔癬, 痂皮, 脱毛, 紅斑を 300 回以上認めた。最も病変 の多い部位は, 前肢および後肢, 腋窩, 後肢足底部であった。病状と解剖学的部位とは, 顕著な相 関（カイ二乗検定， $\mathrm{p}<0.0001 ）$ が存在した。まとめ：南オーストラリアにおけるアルパカの亜集団 におけるこの調査は, 被験個体群の約 $60 \%$ に皮膚病変を保有していることが判明した。主な病状 と病変部位から，被毛の価值に影響を及ぼさないだろうと推測された。

キーワード：アルパカ, ラクダ科, 皮膚, 皮膚科学, 病変
\end{abstract}

(Jpn J Vet Dermatol 2016, 22 (2): 83-90)

\section{Introduction}

* Correspondence to: Thomas W. Westermann, (School of Animal and Veterinary Sciences, The University of Adelaide), South Australia 5371, Australia TEL +61-4-3732-9973

Email: thomas.westermann@student.adelaide.edu.au
Alpacas (Vicugna pacos) are members of the Camelidae family, and one of four species of South American camelid ${ }^{9}$. There are two breeds of alpaca; Huacaya with short, crimped and spongy fibre, and Suri, 
with long, straight fibre that hangs in ringlets ${ }^{10)}$. As of December 2014 there were greater than 166,000 alpacas registered with the Australian Alpaca Association, approximately 10,000 of which resided in South Australia (SA). Including unregistered animals, the national herd is estimated to be greater than 200,000 animals (personal communication, Brown K. Australian Alpaca Association, 18 December 2014). As a result of the growing popularity of alpacas in Australia and internationally there is an increasing demand for veterinary care ${ }^{4,5,7-9,14)}$.

The Australian alpaca industry is currently attempting to redefine itself as a commercial fibre producing industry, in the face of issues such as inconsistency in quality and low volumes of fleece $\mathrm{e}^{2,3,12)}$. It is possible that skin disease is contributing to decreased producer profit, due to lower volumes of usable fibre produced by affected animals and increased processing costs. Before attempts can be made to quantify the economic losses associated with skin disease due to associated veterinary costs, decreased animal value and impact on fleece quality, a greater knowledge of dermatological disease in Australian alpacas is required.

Although the normal anatomy of alpaca skin has been well characterised ${ }^{7,9,10)}$, there is scant information concerning dermatological conditions in alpacas in English scientific literature, aside from extrapolations from llamas and mixed camelid reviews, or anecdotal reports ${ }^{6,14)}$. Previous studies have estimated that the prevalence of skin disease in alpacas is $9 \%$ in the United Kingdom (UK) and 5.6\% in the United States $(\mathrm{US})^{6,14)}$. In Australia no such literature exists, nor even a list of commonly seen dermatological conditions. The aim of this study was to observe and characterise dermatological lesions in SA alpacas from the Fleurieu Peninsula, Adelaide Hills and Mid-North regions during shearing time. Such data will be valuable in informing guidelines on routine veterinary care for alpacas, and provide an insight into the likely prevalence of skin disease in the SA population.

\section{Materials and Methods}

Skin lesions were observed and recorded by professional alpaca shearers over a 16 day period in SA during spring 2013 (21 September 2013 to 6 October 2013). Three different geographical regions within SA were surveyed: the Fleurieu Peninsula, Adelaide
Hills and the Mid-North. Two alpaca shearers, from two alpaca shearing enterprises participated in data collection (Trevor Edmunds, Jut Jura Alpaca Stud, 13 Sixth Street, Booborowie SA 5417; Ben Schmaal, Softfoot Alpaca Farm, 106 Kenny Road, Hindmarsh Valley SA 5211). All involved shearers had several years of professional experience working within the alpaca fleece industry, and underwent an induction program to train them in the usage of the "Skin scoring chart", and how to clearly differentiate between different types of lesions. A written instruction manual was also provided to allow continuous reference.

The Skin scoring chart divided the alpaca's skin surface into 15 anatomical locations (Fig. 1, Table 1). During shearing, shearers annotated this chart with letters that corresponded to specific lesion types (Table 2). Only pre-existing lesions were included; wounds, haemorrhage and alopecia caused by shearing were not scored. Layperson's terminology was used in the induction and instruction manual (shown in italics in Table 2).

Descriptive and summary statistics were calculated using Microsoft Excel. Confidence intervals for prevalence data and lesion type/distribution were calculated using a confidence interval calculator (Confidence Interval Calculator for Proportions, McCallum Layton, Leeds, UK). Associations between lesions types and body regions were analysed using the Chi square test (Chi square calculator, Fourmilab, Walker J, Kent, UK).

\section{Results}

A total of 338 alpacas were included in the study. 162 alpacas were seen on the Fleurieu Peninsula on one property, 120 in the Adelaide Hills on one property and 56 in the Mid-North on twelve properties.

All lesion types included in the scoring chart list were observed at least once during the study, with representative examples of each type shown in Fig. 2. Alpacas often had multiple lesions types at various sites of the body, with lesions seen on all body regions except the tail. A total of 1,856 skin lesions were observed within the sample population (Table 3). The overall prevalence of skin lesions in the surveyed alpacas was $60.4 \pm 5.2 \%$. In the Fleurieu Peninsula, it was $66.7 \%$ (108/162), $60.0 \%$ (72/120) in the Adelaide Hills, and $42.9 \%(24 / 56)$ in the Mid-North.

The frequency with which the various lesion types 


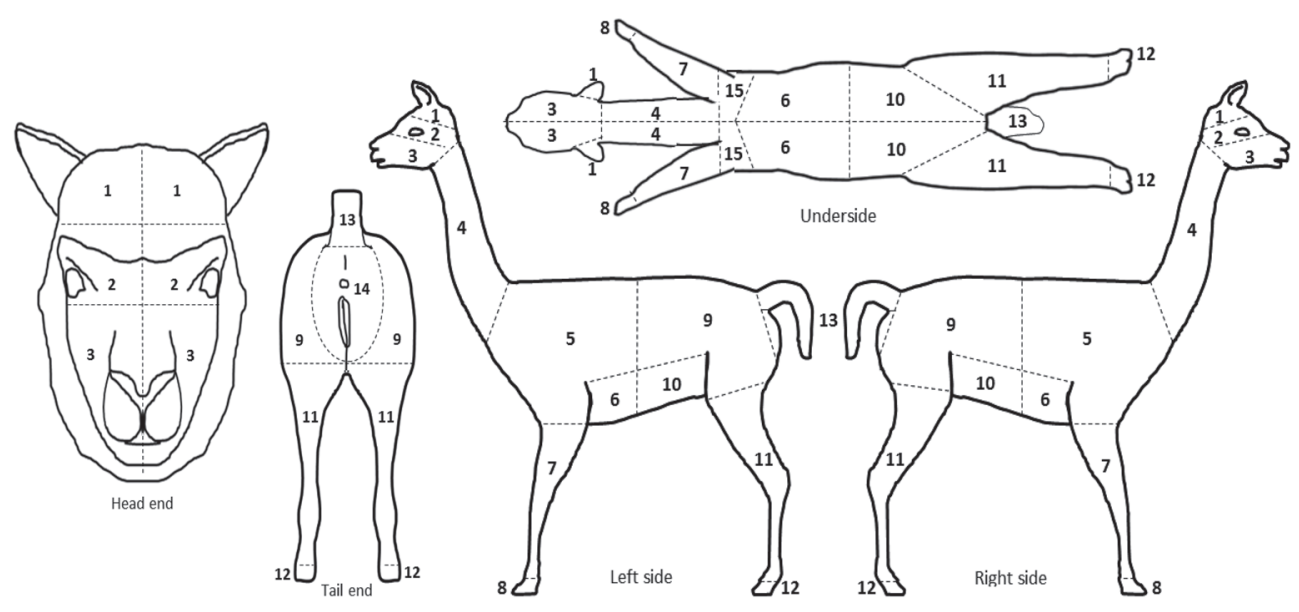

Fig. 1. Diagram showing the anatomical sites examined. Along with Tables 1 and 2, this comprised the Skin scoring chart. The surface of the alpaca was divided into 15 body regions which were examined during shearing. During the data collection process, lesions were recorded for each animal by sketching/circling the affected region on the schematic, before labelling with letters to indicate lesion types. The body areas contained within each subdivision are described in Table 1.

Table 1. Anatomical regions assessed for skin lesions

\begin{tabular}{cll}
\hline No. & Anatomical region & \multicolumn{1}{c}{ Traditional description } \\
\hline 1 & Top of head & Ears, poll and forehead \\
2 & Periorbital & Skin around the eyes \\
3 & Muzzle & Cheeks, and upper and lower jaw \\
4 & Neck & Neck and apron \\
5 & Cranial thorax & Cranial saddle \\
6 & Ventral thorax & Cranial belly \\
7 & Fore limbs & Forearm, knee, cannon, fetlock and pastern \\
8 & Fore feet & Interdigital skin, claw, pad \\
9 & Caudal trunk and flanks & Caudal saddle (loin, croup, caudal ribs and outer thigh) \\
10 & Ventral abdomen & Caudal belly \\
11 & Hind limbs & Inner thigh, stifle, gaskin, hock, cannon, fetlock and pastern \\
12 & Hind feet & Interdigital skin, claw, pad \\
13 & Tail & Tail \\
14 & Perineum & Britching \\
15 & Axillae & Armpits \\
\hline
\end{tabular}

The traditional description incorporates terms that are familiar to alpaca shearers.

were observed at various body sites is shown in Table 3. The most commonly observed lesions were scale and lichenification, crust, alopecia and erythema, each observed over 300 times. The least commonly observed lesions were wounds, scars and the presence of a rash. Lesions were found most frequently on the fore and hind legs, axillae and hind feet. The least commonly affected areas were the ventral thorax, pinnae and tail. There was a significant association between lesion types and anatomical location (Chi square test, $\mathrm{p}<0.0001$ ), indicating that specific lesion types were seen more commonly on particular body regions rather than being randomly distributed over the skin surface. For example, scale, crust and lichenification were seen significantly more commonly on the limbs, whereas lumps and swellings were significantly more common on the saddle region.

Fig. 3 shows the percentage of alpacas that had 
Table 2. Lesion types recorded during the dermatological examinations

\begin{tabular}{ll}
\hline \multicolumn{2}{l}{ Lesion type } \\
\hline A & Alopecia (hair loss) \\
B & Scale or lichenification (scaly or thickened) \\
C & Self trauma (scratched) \\
D & Erythema (reddened or inflamed) \\
E & Rash (spots) \\
F & Crust (scab) \\
G & Wound (skin trauma, e.g. cut) \\
H & Haemorrhage (bleeding) \\
I & Discharge (liquid other than blood, e.g. pus) \\
J & Lumps and swellings \\
K & Scar \\
\hline
\end{tabular}

Layman's terminology used on the score chart during data collection has been italicised. During data collection the schematic shown in Figure 1 was annotated using the appropriate letters.

various types of skin lesions. The results mirror those shown in Table 3, and indicate that the skin lesions observed were encountered in large numbers of alpacas, rather than concentrated in a few individuals. Fig. 4 shows the percentage of alpacas that had skin lesions at various body sites. Again, the results approximate those shown in Table 3, with the exception that the axillae were the second most commonly affected area rather than the forelimbs. The discrepancy arises because overall, more lesions were observed on the forelimbs (typically scale, crust, lichenification) than the axillae, even though more alpacas had an observable lesion in the axillae (typically alopecia) compared to the forelimbs.

\section{Discussion}

In this study of South Australian alpacas there was a high prevalence of skin lesions. Over $60 \%$ of those sheared had one or more skin lesions on their body. This figure is much higher than the $9 \%$ prevalence reported by D'Alterio et al. in UK alpacas. However, in that study, the data was obtained from alpaca owners via a postal survey. Hence, the lower figure could be attributed to the owner's opinion of what constituted a skin disease, and could also reflect lack of observation. Many skin lesions can be covered by the alpaca's fleece and it is possible that many lesions would go unnoticed apart from at shearing. In a report by Scott et al., 5.6\% of 715 alpacas presenting to a University veterinary hospital were diagnosed with a skin disease. Again, this lower figure could reflect the different criteria applied in the different studies. In Scott's study, only those alpacas with a clinically relevant skin disease were included, whereas in this study, any alpaca with a skin lesion was included, even if it was very mild or clinically asymptomatic. It should also be noted that this study only sampled a small proportion of the South Australian alpaca population in three restricted geographical locations, and the prevalence data cannot be extrapolated to the national herd. However, despite this, it is clear that the presence of skin lesions is a common finding in alpacas living in Australia. Effects such as climate, husbandry practices and the provision of routine veterinary care could vary from region to region, possibly explaining the difference observed in the prevalence of skin lesions between the Mid-North and other regions. Comparative analysis of skin lesion types and bodily distributions between geographical regions was not undertaken.

Possible aetiologies of skin disease in alpacas can include ectoparasitic, bacterial, fungal, viral, neoplastic and non-neoplastic tumours, environmental, physical, nutritional, congenital and idiopathic causes ${ }^{8,10,11,13,14)}$. Some of the most commonly identified lesions in this study were scale, crust, lichenification, alopecia and erythema, especially on the limbs and feet. Such lesions were found in $30-40 \%$ of the alpacas. D'Alterio et al. found that respondents in his survey also reported hair loss, crusty/ scabby skin, scaly/ thickened skin and reddened skin as the most common lesions ${ }^{6)}$. These lesion types would most likely be associated with conditions such as ectoparasite infestation, bacterial infection, zinc responsive dermatosis or environmental influences, although precise diagnosis would require further evaluation and investigation by a veterinarian. Zinc responsive dermatosis was diagnosed in $23 \%$ of the alpacas in the UK study by D'Alterio et al. ${ }^{6)}$ and ectoparasitic infestation accounted for $19 \%{ }^{6)}$ and $10 \%{ }^{14)}$ of the diagnoses in the UK and US studies respectively. In this study, alopecia was commonly seen on the limbs and in the axillae and was observed in about $30 \%$ of alpacas. Although alopecia could be associated with the skin conditions mentioned above, the high frequency with which this lesion type was observed in the axillae could reflect the normal sparsity of the hair coat that occurs in 


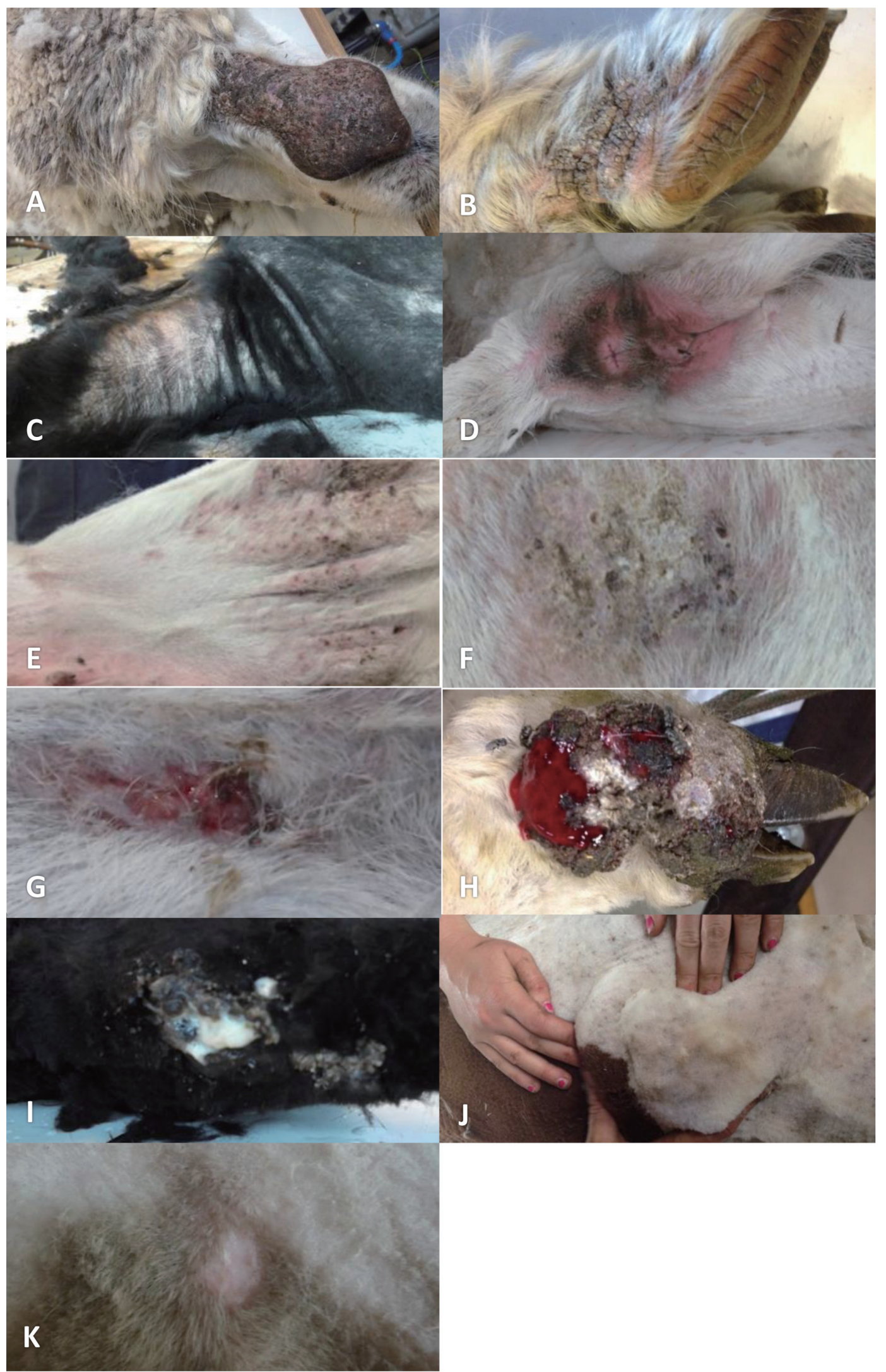

Fig. 2. Representative lesion types observed in SA alpacas. A. Alopecia; B. Scale or lichenification; C. Self trauma; D. Erythema; E. Rash; F. Crust; G. Wound; H. Haemorrhage; I. Discharge; J. Cutaneous lumps or swellings; K. Scar. 


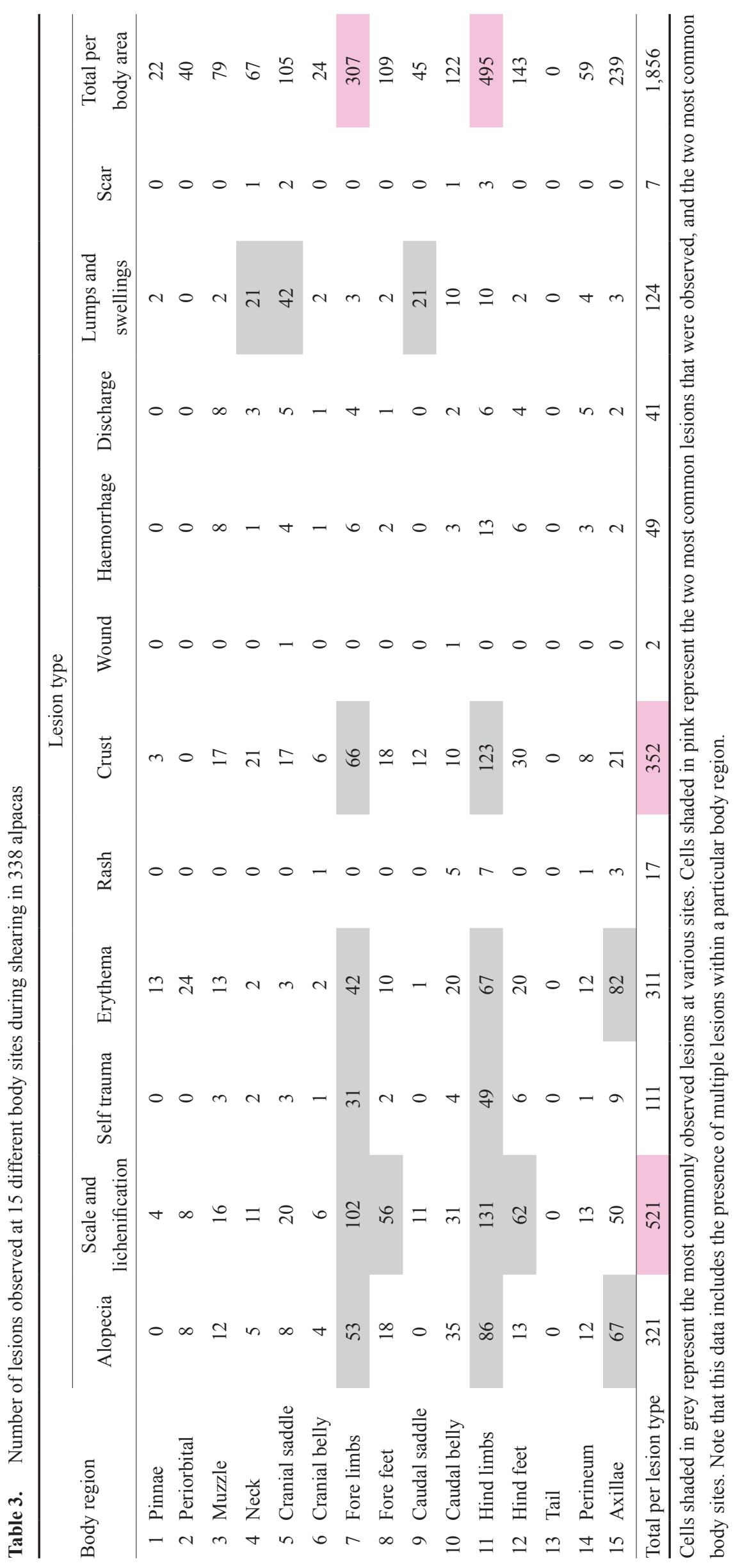




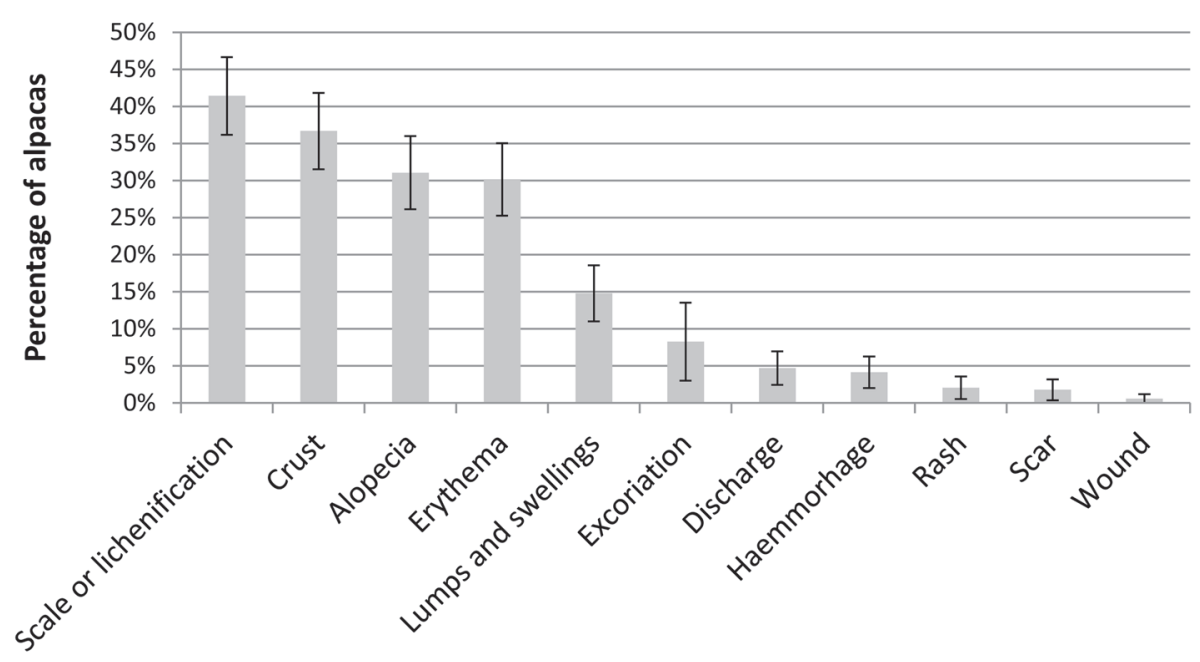

Fig. 3. Lesion types observed in SA alpacas during shearing. Columns represent the percentage of alpacas in which a particular lesion was seen. The error bars indicate the confidence intervals.

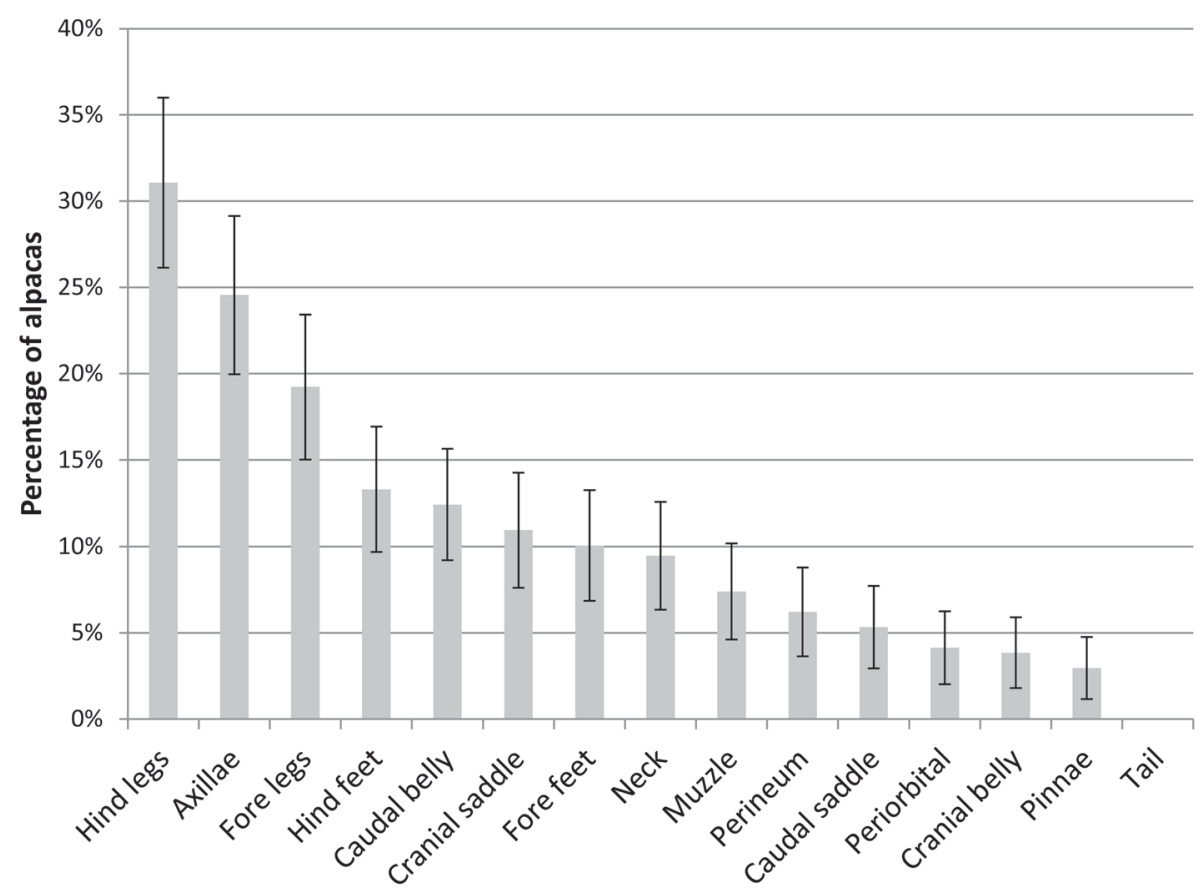

Fig. 4. Body sites affected by skin lesions in SA alpacas. Columns represent the percentage of alpacas in which a particular body site was affected. The error bars indicate the confidence intervals.

this region. There was also a relatively high frequency of alpacas with cutaneous lumps and swellings, present in almost $15 \%$. These ranged from solitary to widespread masses, most often observed in the saddle and neck regions. These could have been neoplastic tumours such as fibropapillomas, fibromas, or trichoepitheliomas, or non-neoplastic lesions such as follicular cysts, hamartomas or abscesses ${ }^{14)}$. Scott et al. found that neoplastic and non-neoplastic tumours accounted for $19 \%$ of diagnosed skin diseases in alpacas ${ }^{14)}$.

The presence of skin lesions in alpacas has been suggested to have an economic impact (personal communication, Porter J. Australian Fibre Network Association, 24 October 2013). However, the results of 
this study have indicated that the majority of skin lesions in SA alpacas occurred on the limbs, feet and ventrum. These areas are of lower fleece quality, so any impact on producer profit due to skin disease in these regions is likely to be minimal. The primary body region of interest in terms of fleece value is the saddle (i.e. 'blanket', areas 5 and 9 in Fig. 1) ${ }^{1}$. The major lesion types occurring in these areas were cutaneous lumps and swellings which are unlikely to significantly decrease fleece production, diminish fleece quality, or increase processing costs ${ }^{2)}$.

In summary, skin lesions were common in SA alpacas, occurring in approximately $60 \%$ of animals. Scaling and crusting lesions on the limbs were particularly common, although these would not greatly influence the value of fleece. In this study the skin lesions were not identified by qualified veterinarians or dermatologists. Hence, it is not possible to indicate the precise diagnosis for the conditions seen. Further studies should extend these observations to include cases examined by veterinarians to establish precise diagnoses, so that such epidemiological data is available. Investigation is also required to elucidate other possible costs associated with skin disease, such as decreased animal value and any associated treatment expenses.

\section{Acknowledgements}

We acknowledge the generous assistance with data collection provided by Ella Carapetis, Nicole Edmunds, Trevor Edmunds, Ben Schmaal and the owners of all properties involved. Thanks also to Dr. Charles Caraguel, Dr. Michael Riechel and Dr. Darren Trott, for providing their expertise. This study was funded by the School of Animal and Veterinary Science, the University of Adelaide.

\section{References}

1. Alpaca Llama Show Association. 2005. Youth Judging Manual: Alpaca Llama Show Association. pp. 1-48. In: ALSA, Alpaca Llama Show Association, Texas.

2. Australian Alpaca Fleece Limited. 2010. AAFL Fleece Handling Manual. pp. 1-8. In: AAFL article, Australian Alpaca Fleece Limited, Victoria.

3. Australian Alpaca Fleece Limited. 2008. The
Australian Alpaca Fleece Industry. pp. 1-3. In: AAFL article, Australian Alpaca Fleece Limited, Victoria.

4. Brandon, A. 2011. Dermatological disease, aetiology and treatment in the South American camelid: a systematic literature review. pp. 1-13. In: Alpacas Australia, Alpacas Australia, Victoria.

5. D'Alterio, G.L. 2006. Skin lesions in UK alpacas (Lama pacos): Prevalence, aetiology and treatment. pp 121-131. In: South American Camelids Research Vol 1, Proceedings, $4^{\text {th }}$ European Symposium on South American Camelids, Wageningen Academic Publishers, Gottingen.

6. D’Alterio, G.L., Knowles, I.G., Eknaes, E.I., Loevland, I.E. and Foster, A.P. 2006. Postal survey of the population of South American camelids in the United Kingdom in 2000/01. Vet. Rec. 158: 86-90.

7. Fleis, R.I. and Scott, D.W. 2010. The microanatomy of healthy skin from alpacas (Vicugna pacos). $J$. Vet. Diagn. Invest. 22: 716-719.

8. Foster, A. 2008. Skin diseases of South American camelids. pp. 30-32. In: Procedings of the Spring Meeting: Artichokes to zebra; all you need to know about herbivores, British Veterinary Zoological Society, Bedford.

9. Foster, A., Jackson, A. and D'Alterio, G.L. 2007. Skin diseases of South American camelids. In Pract. 29: 216-223.

10. Fowler, M.E. 2010. Integumentary System. pp. 289-311. In: Medicine and Surgery of Camelids. Wiley-Blackwell, Iowa.

11. Hensel, P. 2010. Nutrition and skin diseases in veterinary medicine. Clin. Dermatol. 28: 686-693.

12. McGregor, B.A. 2006. Production, attributes and relative value of alpaca fleeces in southern Australia and implications for industry development. Small Ruminant Res. 61: 93-111.

13. Plant, J.D., Kutzler, M.A. and Cebra, C.K. 2007. Efficacy of topical eprinomectin in the treatment of Chorioptes sp infestation in alpacas and llamas. Vet. Dermatol. 18: 59-62.

14. Scott, D.W., Vogel, J.W., Fleis, R.I., Miller, W.H. and Smith, M.C. 2011. Skin diseases in the alpaca (Vicugna pacos): a literature review and retrospective analysis of 68 cases (Cornell University 1997-2006). Vet. Dermatol. 22: 2-16. 